\title{
CHINESE YEARBOOK OF INTERNATIONAL LAW AND AFFAIRS
}

Vol. 13 (1994-1995)

Edited by Hungdah Chiu. 800 pp., Index.

\begin{abstract}
Articles
Lee Teng-hui, Always in My Heart
\end{abstract}

The First Asian-Pacific Regional Conference of the International Law Association (ILA), May 27-30, 1995: Fredrick F. Chien, Keynote Speech; Report of the International Law Association (ILA) Committee on International Law in National Courts in ILA First Asian-Pacific Regional Conference; John King Gamble, International Law Research in the Information Age; Donald R. Rothwell, The Law of the Sea in the Asian-Pacific Region: An Overview of Trends and Developments; John Prebble, Philosophical and Design Problems that Arise from the Ectopic Nature of Income Tax Law and Their Impact on the Taxation of International Trade and Investment; Charlotte Ku, The Developing Role of Non-Governmental Organizations in Global Policy and Law Making; Closing Ceremony; Lee Teng-hui, Remarks to Foreign Participants of the First Asian-Pacific Regional Conference of the International Law Association; Ricardo R. Balestra, Response to President Lee Teng-hui's Remarks

Recent Developments

Response of the Chinese [Taiwan] Branch of the International Law Association and the Judicial Yuan of the Republic of China to the Questionnaire of the International Law Association Regarding the International Law Practice in the Municipal Courts of the Republic of China; Ying-jeou Ma, War on Drugs; Bin Cheng, How Should We Study International Law?; Chun-i Chen, A Comment on the Recent United Nations Peacekeeping Operation in the Former Yugoslavia; Stephen Kho, Article 73 of the Vienna Convention on Consular Relations: The Relationship between the Vienna Consular Convention and Other International Consular Agreements

Contemporary Practice and Judicial Decisions of the Republic of China Relating to International Law, 1993-1995, compiled by Hungdah Chiu and Su Yun Chang with the assistance of I-hsin Huang and David Salem

Book Reviews

Book Summaries

List and Text of Bilateral Treaties/Agreements and Official, Semi-Official or Unofficial Agreements Concluded by the Republic of China with Other Countries in 1994, compiled by Hungdah Chiu and Su Yun Chang

List and Text of Agreements Concluded between the American Institute in Taiwan (AIT) and the Coordination Council for North American Affairs (CCNAA)/Taipei Economic and Cultural Representative Office in the United States (TECRO) in 1994, compiled by Hungdah Chiu and Su Yun Chang

\section{Order/Subscription Information}

Price -- Subscription price is U.S. $\$ 28.00$. For air mail, please add $\$ 30.00$. Individual order is accepted at the same price as subscription, but please add postage/handling of $\$ 5.00$ (U.S.) or $\$ 8.00$ (overseas) for one copy. All back issues are available at the same price.

Order/Subscription and Inquiry should be sent to:

Managing Editor, OPRSCAS

University of Maryland School of Law

500 West Baltimore Street

Baltimore, MD 21201, U.S.A.

Check should be made payable to Chinese Yearbook of International Law \& Affairs (or CYILA). Inquiry on order/subscription should be referred to the Managing Editor at TEL (410) 7063870, FAX (410) 706-4045. Institution/Library may request billing before making payment. National Branches of the International Law Association may request to exchange their publication with the Yearbook. 